\title{
Seroprevalensi dan Faktor Risiko Rabies pada Anjing di Daerah Endemis Kabupaten Sukabumi
}

\section{(Seroprevalence and Risk Factors of Rabies on Dogs in the Endemic Area of Sukabumi District)}

\author{
Ardilasunu Wicaksono ${ }^{1 *}$, Abdul Zahid ${ }^{1}$, Etih Sudarnika ${ }^{1}$, Dordia Anindita Rotinsulu ${ }^{1}$, Denny Widaya \\ Lukman ${ }^{1}$, Sri Murtini ${ }^{1}$, Yusuf Ridwan ${ }^{1,2}$ \\ (Diterima Agustus 2020/Disetujui Juli 2021)
}

\begin{abstract}
ABSTRAK
Kabupaten Sukabumi dilaporkan masih sebagai daerah endemis rabies di Provinsi Jawa Barat. Untuk mendukung keberhasilan program pengendalian rabies, perlu diketahui tingkat kejadian rabies sebagai informasi dasar guna menurunkan kasus rabies. Penelitian ini bertujuan menetapkan seroprevalensi rabies dan mengidentifikasi faktor risiko yang berhubungan dengan kejadian rabies di wilayah di Kecamatan Jampang Tengah dan Cisolok yang masih memiliki kasus rabies positif pada anjing dan manusia. Sampel yang digunakan adalah darah 191 ekor anjing untuk diukur titer antibodi rabies dan dipilih dengan metode penarikan contoh acak sederhana. Titer antibodi diukur menggunakan enzyme-linked immunosorbent assay dan faktor risiko diidentifikasi menggunakan data hewan yang dibagi menjadi data intrinsik dan ekstrinsik. Data dianalsis menggunakan uji chi square dan menghitung odds ratio. Hasilnya menunjukkan bahwa seroprevalensi rabies adalah 7,9\% (4,9-10,9\%). Rataan titer antibodi adalah $0,23 \mathrm{EU}$ dengan nilai minimum 0,03 EU dan nilai maksimum 0,96 EU. Pada anjing yang belum divaksinasi, terdapat 7,8\% dari populasi yang menunjukkan seropositif rabies sedangkan pada anjing yang telah divaksinasi hanya ada $8,0 \%$ dari populasi yang memiliki titer antibodi protektif rabies. Faktor risiko yang berpengaruh nyata pada seroprevalensi rabies pada anjing adalah wilayah pemeliharaan $(p=0,003)$ yang memperlihatkan bahwa anjing yang dipelihara di wilayah pesisir pantai memiliki kemungkinan $5,8(1,6-21,2)$ kali lebih besar seropositif terhadap rabies dibandingkan dengan anjing yang dipelihara di wilayah perbukitan.
\end{abstract}

Kata kunci: anjing, faktor risiko, rabies, seroprevalensi, titer antibodi

\section{ABSTRACT}

Sukabumi District is reported to date as an endemic rabies area in West Java Province. In supporting the rabies control programs, the occurrence of rabies needs to be determined to decrease the number of cases. This research aims to determine the seroprevalence of rabies and identify the risk factors associated with rabies in the district. The research was conducted in Jampang Tengah and Cisolok sub-districts with positive rabies cases on dogs and humans. The blood samples were taken from 191 selected dogs using simple random sampling. Rabies antibody titer was measured using ELISA, and the risk factor was identified using selected dogs' data classified into intrinsic and extrinsic characteristics. Data were analyzed using the chi-square test and the calculation of the odds ratio. The results showed that the seroprevalence of rabies was $7.9 \%(4.9-10.9 \%)$. The average antibody titer was 0.23 EU with a minimum value of $0.03 \mathrm{EU}$ and a maximum of $0.96 \mathrm{EU}$. Thus, as high as $7.8 \%$ of the population showed rabies seropositivity from the unvaccinated dogs, while among the vaccinated dogs, only $8.0 \%$ of the population with rabies protective antibody titer. The significant risk factor of rabies seroprevalence is the typology of raising area $(p=0.003)$, revealing that the dogs raised in the coastal area had the odds of $5.8(1.6-21.2)$ higher to get the rabies seropositivity than the dogs raised in the highland area.

Keywords: antibody titre, dogs, rabies, risk factor, seroprevalence

\section{PENDAHULUAN}

Rabies merupakan masalah kesehatan masyarakat yang serius dan masih menjadi perhatian di negara-

1 Departemen Ilmu Penyakit Hewan dan Kesehatan Masyarakat Veteriner, Fakultas Kedokteran Hewan, Institut Pertanian Bogor, Kampus IPB Darmaga, Bogor 16680

${ }^{2}$ National Zoonosis Center, Lembaga Penelitian dan $\mathrm{Pe}$ ngabdian Masyarakat, Institut Pertanian Bogor, Kampus IPB Darmaga, Bogor 16680

* Penulis Korespondensi: Email: vetsunuedu@gmail.com negara di dunia utamanya negara-negara berkembang (Knobel et al. 2005; Wilde et al. 2007; Tenzin et al. 2012). Di Indonesia, kasus rabies masih terjadi baik pada hewan pembawa rabies terutama anjing dan pada manusia yang menjadi korban. Rabies merupakan penyakit endemik di Indonesia yang menyebar di 24 dari 33 provinsi dan terdapat rata-rata sebanyak 150-300 kasus kematian manusia akibat rabies setiap tahun (Nugroho et al. 2013).

Kabupaten Sukabumi dilaporkan masih sebagai daerah positif kasus rabies yang turut berkontribusi dalam program eradikasi rabies di Provinsi Jawa Barat. 
Kasus rabies terkonfirmasi positif di kabupaten ini terbanyak pada tahun 2008 yang terjadi di 5 kecamatan, yakni Jampang Tengah, Cisolok, Cikembar, Jampang Kulon, dan Cimanggu. Pada tahun-tahun selanjutnya kejadian positif rabies terjadi di Kecamatan Tegalbuleud pada 2010 dan Kecamatan Nyalindung pada 2015 dan 2016 (Dinas Peternakan Kabupaten Sukabumi 2016).

Dalam rangka mengendalikan rabies, perlu diketahui tingkat kejadian penyakit rabies terkini sebagai informasi dasar untuk mencapai target pengendalian rabies yang diharapkan. Tingkat kejadian penyakit rabies dapat diukur dengan menilai besaran seroprevalensi rabies di daerah tersebut, selain perlu diidentifikasi faktor-faktor risiko yang berkaitan dengan kejadian rabies sehingga intervensi pengendalian dapat lebih terarah untuk mengurangi atau menghilangkan faktor-faktor tersebut dalam rangka mencegah kasus rabies. Kurangnya data faktor risiko memengaruhi ketidakefektifan pengambilan kebijakan oleh pemerintah dalam menentukan program pengendalian yang tepat (Hampson et al. 2005; Salomao et al. 2017).

Tujuan penelitian ini adalah menetapkan besaran seroprevalensi rabies dan mengidentifikasi faktorfaktor risiko yang berhubungan dengan kejadian rabies di wilayah Kabupaten Sukabumi, Jawa Barat. Hipotesis dalam penelitian ini adalah terdapat hubungan yang nyata antara faktor-faktor risiko yang diidentifikasi dengan kejadian rabies tersebut.

\section{METODE PENELITIAN}

\section{Waktu dan Tempat Penelitian}

Penelitian dilaksanakan pada bulan Juli sampai November tahun 2017. Data dikumpulkan di dua kecamatan yang ada di Kabupaten Sukabumi, yakni Kecamatan Jampang Tengah dan Kecamatan Cisolok. Kecamatan Jampang Tengah dipilih karena masih memiliki kejadian kasus rabies positif pada anjing dan manusia pada tahun 2016 (Dinas Peternakan Kabupaten Sukabumi 2016) dan mewakili daerah dataran tinggi yang berbukit, sementara Kecamatan Cisolok dipilih karena berbatasan langsung dengan Provinsi Banten yang tengah menjalankan program eradikasi rabies dan mewakili daerah dataran rendah pesisir pantai. Sampel hayati diuji di Laboratorium Mikrobiologi; perancangan dan data dianalisis di Laboratorium Epidemiologi, Fakultas Kedokteran Hewan Institut Pertanian Bogor.

\section{Jenis dan Besaran Sampel}

Sampel dalam penelitian ini adalah anjing yang dimiliki oleh masyarakat yang biasa digunakan sebagai hewan penjaga rumah/ladang dan hewan berburu. Sampel darah dikoleksi untuk pengukuran titer antibodi terhadap penyakit rabies. Besaran sampel dihitung menggunakan rumus untuk menduga prevalensi penyakit (Dohoo et al. 2009; Thrusfield 2018):

$$
n=\left(z_{0.05}\right)^{2} \times P_{\exp } \times\left(1-P_{\exp }\right) / d^{2}
$$

Keterangan:

$$
\begin{array}{ll}
n & =\text { Besaran sampel } \\
Z_{0.05} & =\text { Nilai } z \text { pada selang kepercayaan } 95 \%(1,96) \\
P_{\exp } & =\text { Prevalensi dugaan } \\
d & =\text { Tingkat kesalahan yang diharapkan }
\end{array}
$$

Pada penelitian ini digunakan asumsi prevalensi dugaan sebesar $18 \%$, selang kepercayaan 95\% (Wicaksono dan Sudarwanto 2016), dan tingkat kesalahan 5\%; maka didapatkan besaran sampel minimal adalah 185 ekor. Pada penelitian, sampel diambil lebih banyak, yaitu 191 ekor, terbagi ke dalam 107 ekor di Kecamatan Jampang Tengah dan 84 ekor di Kecamatan Cisolok. Sampel dipilih dengan metode penarikan sampel acak sederhana. Data lain yang dikumpulkan adalah data karakteristik anjing seperti jenis kelamin, umur, tipe pemeliharaan, dan status vaksinasi rabies untuk mengidentifikasi faktor-faktor yang memengaruhi titer antibodi rabies pada anjing.

\section{Koleksi Sampel}

Anjing ditangani dengan hati-hati untuk menghindari penderitaan yang tidak perlu dan sampel darah dikoleksi sebanyak $2 \mathrm{~mL}$ dari pembuluh vena saphena. Setelah dikoleksi, serum dipisahkan dengan cara didiamkan 30-60 menit setelah diambil. Sampel kemudian diberi label pada bagian atas plastik pembungkus yang meliputi kode kabupaten, kecamatan, pemilik, jenis kelamin anjing, kelompok umur anjing, dan nomor sampel. Sampel kemudian disimpan di dalam cool box yang telah berisi es batu lalu disimpan di dalam lemari pembeku di laboratorium sampai saatnya diperiksa. Selanjutnya, sampel dipindahkan ke rantai dingin (suhu $4-8^{\circ} \mathrm{C}$ ). Serum dipisahkan dari darah setelah 24 jam penyimpanan di dalam lemari pendingin (suhu $4^{\circ} \mathrm{C}$ ) lalu serum diinaktivasi selama 30 menit pada suhu $56^{\circ} \mathrm{C}$.

\section{Pengukuran Seroprevalensi Rabies}

Seroprevalensi rabies ditentukan dengan mengukur titer antibodi rabies yang ada pada sampel serum darah menggunakan enzyme-linked immunosorbent assay (ELISA). Metode uji menggunakan sediaan kit Indirect ELISA Rabies Demeditec $\AA$ (DemitecDiagnostics $\mathrm{GmbH}$ ), yang terdiri atas mikroplat 96 sumuran tersalut dengan antigen rabies, kontrol positif serum yang mengandung antibodi rabies dan timerosal 0,01\% dengan konsentrasi $4 \mathrm{EU}$, kontrol negatif serum, konjugat Peroksidase-rec-Protein $A$, larutan ABTS, phosphate-buffered saline (PBST) konsentrasi 10 kali, larutan stopper, dan plastik absorben. Hasilnya dibaca dengan mesin pembaca ELISA pada panjang gelombang $405 \mathrm{~nm}$.

\section{Metode Uji}

Prosedur uji sesuai dengan petunjuk kerja kit ELISA rabies Pusvetma. Serum kontrol positif K4EU, K2EU, $\mathrm{K} 1 \mathrm{EU}, \mathrm{K} 0,5 \mathrm{EU}, \mathrm{K0}, 25 \mathrm{EU}$, dan K0,125EU; serum 
kontrol ST1EU, serum kontrol negatif, dan serum sampel yang sudah diencerkan dimasukkan ke dalam sumuran mikroplat sebanyak $100 \mu \mathrm{l}$ (duplo) sesuai dengan urutan. Pada sumuran $\mathrm{H} 11$ dan $\mathrm{H} 12$ ditambahkan $100 \mu \mathrm{L}$ PBST sebagai blangko. Mikroplat ditutup dengan plastik adsorben dan inkubasikan pada suhu $37^{\circ} \mathrm{C}$ selama 60 menit. Tutup plastik adsorben dibuka dan cairan dalam mikroplat dibuang, kemudian dicuci dengan volume minimal $200 \mu \mathrm{l}$ PBST setiap sumuran sebanyak 4-5 kali dan tapping hingga tidak ada gelembung udara di dalam sumuran. Konjugat Protein A pengenceran 1:16000 sebanyak $100 \mu \mathrm{L}$ ditambahkan pada setiap sumuran di mikroplat. Mikroplat ditutup dengan pastik penutup dan inkubasikan pada suhu $37^{\circ} \mathrm{C}$ selama 60 menit. Cairan pada mikroplat dibuang, lalu mikroplat dicuci dengan volume minimal $200 \mu \mathrm{L}$ PBST setiap sumuran sebanyak 4-5 kali dengan tapping hingga tidak ada gelembung udara di dalam sumuran. Sebanyak $100 \mu \mathrm{L}$ larutan substrat ditambahkan di setiap sumuran dan dipindahkan ke tempat gelap selama 10 menit (larutan stopper ditambahkan bila terjadi perubahan warna dengan cepat, waktu diperpanjang jika reaksi lambat). Larutan stopper sebanyak $100 \mu \mathrm{L}$ ditambahkan di setiap sumuran kemudian dibaca dengan alat baca ELISA pada panjang gelombang $405 \mathrm{~nm}$.

\section{Pembacaan Hasil}

Hasil pembacaan diplotkan dengan membuat garis persamaan pada program Microsoft Excel. Data serum kontrol dan serum sampel dipindahkan kemudian dibuat nilai rata-rata, grafik serum kontrol $(+)$ dan negatif (-) dibuat, densitas optis (OD) kontrol positif dan kontrol negatif tidak boleh bersinggungan, grafik selisih nilai OD antara kontrol positif dan negatif dibuat, garis logaritmik sebagai garis koreksi dan garis positif murni ditentukan, hasil akhir pada pengujian ELISA dinyatakan dalam kesetaraan ekuievalen unit (EU). Hasil uji ditafsir sebagai berikut: sampel dengan titer antibodi $\geq 0,5 \mathrm{EU}$ adalah positif yang menandakan nilai titer serum cukup, dan sampel dengan titer antibodi < $0,5 \mathrm{EU}$ adalah negatif yang menandakan nilai titer serum tidak cukup (Dartini et al. 2012).

\section{Identifikasi Faktor Risiko}

Faktor risiko rabies diidentifikasi menggunakan data sampel anjing yang diperoleh. Selanjutnya, faktor risiko dihubungkan dengan hasil seroprevalensi rabies. Faktor risiko yang diidentifikasi dibagi menjadi faktor risiko intrinsik dan ekstrinsik. Faktor risiko intrinsik berasal dari karakteristik intrinsik anjing yang meliputi jenis kelamin, umur, dan status vaksinasi rabies, sedangkan faktor risiko ekstrinsik meliputi tipe pemeliharaan dan wilayah pemeliharaan anjing tersebut.

\section{Analisis Data}

Data dianalisis secara deskriptif dan analitis. Data yang disajikan secara deskriptif meliputi hasil uji titer antibodi dan besaran seroprevalensi rabies. Secara analitis, data diuji secara statistik menggunakan uji chisquare (Roy \& Hossain 2014, Wicaksono et al. 2017) dan uji derajat asosiasi Odds Ratio untuk melihat keberadaan hubungan yang signifikan antara faktorfaktor risiko yang diidentifikasi dengan hasil seroprevalensi rabies (Dahlan 2014; Wicaksono et al. 2019). Data dianalisis dengan menggunakan program perangkat lunak SPSS Versi 16 dan Microsoft Excel 2010.

\section{HASIL DAN PEMBAHASAN}

\section{Seroprevalensi Rabies}

Titer antibodi rabies telah diukur untuk menilai seroprevalensinya pada anjing berpemilik yang umumnya dipelihara dengan cara dilepasliarkan oleh para penduduk setempat di Kabupaten Sukabumi. Hasil pengukuran besaran seroprevalensi rabies pada anjing (Tabel 1) adalah 7,9\% (4,9-10,9\%), sementara itu hasil yang menunjukkan seronegatif atau titer antibodi di bawah 0,5 EU adalah 92,1\% (90,1-94,2\%). Hal ini menunjukkan mayoritas sampel mempunyai tingkat kekebalan rabies yang rendah pada anjing yang dipelihara di Kabupaten Sukabumi. Namun, data dapat juga memperlihatkan kekebalan alami pada beberapa anjing yang diamati yang mengindikasikan keberadaan sirkulasi virus pada populasi hewan secara alamiah.

$\mathrm{Di}$ samping itu, diperoleh informasi mengenai sebaran hasil pengukuran seroprevalensi pada populasi anjing yang diamati. Sebaran hasil pengukuran seroprevalensi disajikan pada Gambar 1. Dapat dilihat bahwa mayoritas titer antibodi rabies pada populasi anjing berada pada area sebelah kiri dari grafik yang menunjukkan bahwa kebanyakan anjing memiliki titer antibodi yang rendah di bawah 0,5 EU. Rata-rata menunjukkan bahwa titer antibodi berada pada nilai 0,23 EU dengan nilai minimum 0,03 EU dan nilai maksimum 0,96 EU.

Keberadaan antibodi spesifik rabies pada anjing sehat dan belum divaksinasi menjadi indikator ada paparan rabies yang bersifat nonletal atau tidak mematikan (Gold et al. 2020). Namun, keberadaan kekebalan alami tersebut di tengah populasi hewan merupakan cara virus untuk mempertahankan eksistensinya di alam (Blackwood et al. 2013). Pada

Tabel 1 Seroprevalensi rabies pada anjing di Kabupaten Sukabumi

\begin{tabular}{|c|c|c|c|c|}
\hline \multirow{2}{*}{ Titer antibodi } & \multicolumn{2}{|c|}{ Ukuran sampel } & \multicolumn{2}{|c|}{ Selang kepercayaan 95\% } \\
\hline & Jumlah sampel & Persentase (\%) & Minimal & Maksimal \\
\hline Positif ( $\geq 0,5 \mathrm{EU})$ & 15 & 7,9 & 4,9 & 10,9 \\
\hline Negatif $(<0,5 \mathrm{EU})$ & 176 & 92,1 & 90,1 & 94,2 \\
\hline Total & 191 & 100 & & \\
\hline
\end{tabular}


anjing yang telah divaksinasi, rendahnya titer antibodi dapat diakibatkan oleh kegagalan vaksinasi akibat faktor dari kualitas vaksin, keterampilan vaksinator, status kesehatan anjing saat divaksinasi, dan pola pemeliharaan (Prasatya et al. 2018). Pada daerah penelitian, mayoritas anjing dipelihara secara dilepasliarkan sehingga memengaruhi buruknya status kesehatan anjing karena pola makan yang tidak teratur dan nutrisi yang tidak tercukupi. Dengan demikian pembentukan antibodi menjadi tidak optimum setelah vaksinasi tersebut, sebagaimana terlihat dari rendahnya titer antibodi pada saat pengamatan.

\section{Faktor Risiko Rabies}

Faktor risiko dari hasil pengukuran titer antibodi rabies pada anjing telah dianalisis. Faktor risiko yang diidentifikasi tersebut dibagi menjadi dua kategori berdasarkan klasifikasi determinan intrinsik dan determinan ekstrinsik. Pada kategori faktor risiko intrinsik, diidentifikasi tiga variabel, yakni jenis kelamin, umur, dan status kekebalan rabies pada anjing akibat vaksinasi. Hasilnya dapat dilihat pada Tabel 2 . Diperlihatkan bahwa dari semua variabel faktor intrinsik yang dianalisis dengan uji chi-square, tidak terdapat variabel yang berhubungan nyata dengan hasil seroprevalensi rabies. Meskipun demikian, ada yang dapat disimpulkan dari analisis odds ratio. Hasilnya menunjukkan bahwa anjing jantan memiliki kemungkinan 1,1 kali memiliki titer antibodi rabies (seropositif) dibandingkan anjing betina, dan anjing berumur muda (< 1 tahun) memiliki kemungkinan 1,3 kali seropositif rabies dibandingkan anjing dewasa $(\geq 1$ tahun). Walaupun jika dilihat dari nilai odds-nya tidak begitu berbeda karena hasilnya mendekati angka satu pada kedua kelompok populasi anjing. Hasil ini juga selaras dengan penelitian Jakel et al. (2008) bahwa jenis kelamin anjing tidak berpengaruh pada titer antibodi rabies.

Khusus pada variabel umur, juga dianalisis regresi untuk mengevaluasi hubungan antara umur dan besaran titer antibodi (Gambar 2). Terdapat korelasi negatif antara umur dan nilai titer antibodi. Terlihat

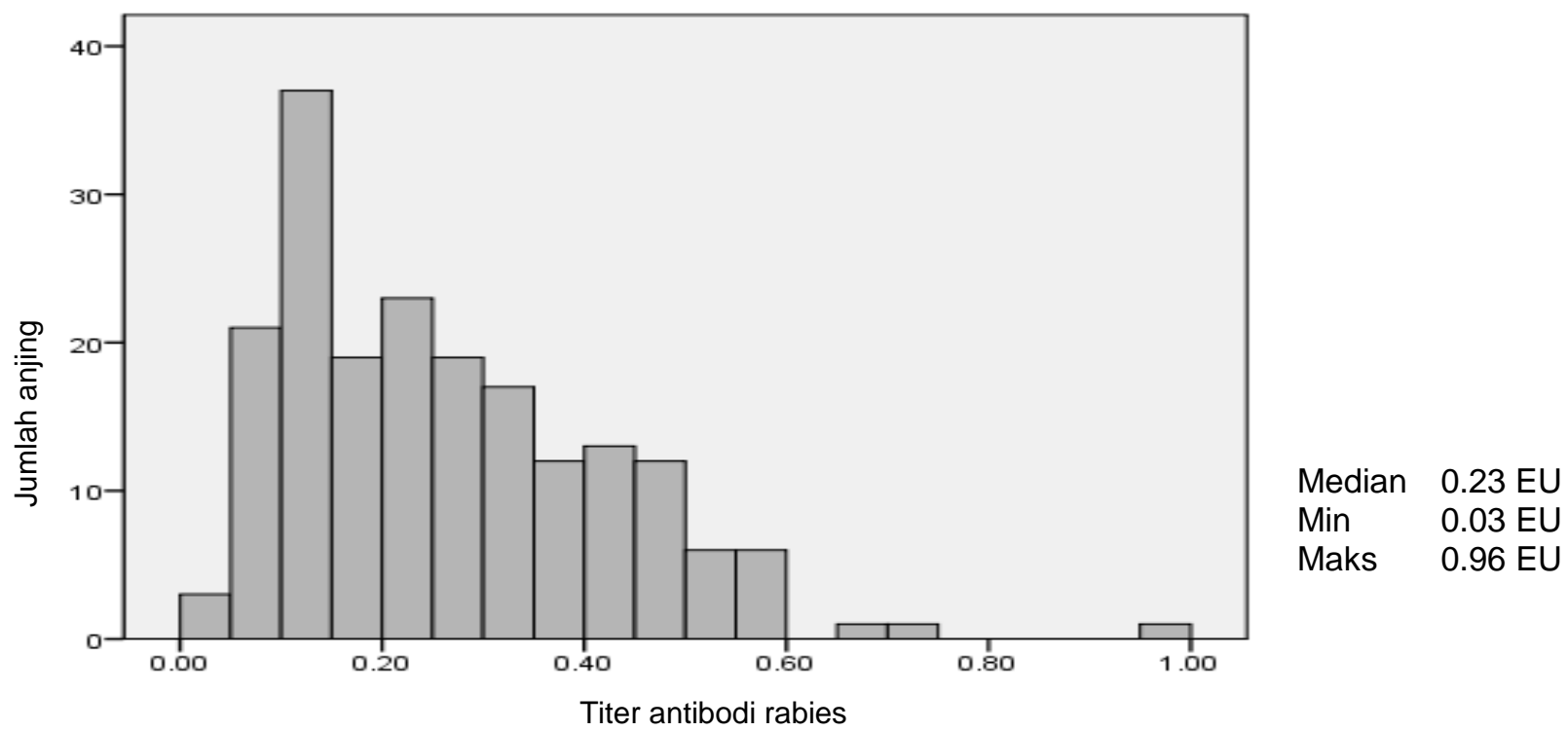

Gambar 1 Sebaran hasil pengukuran titer antibodi rabies pada anjing.

Tabel 2 Faktor risiko intrinsik terhadap seroprevalensi rabies pada anjing di Kabupaten Sukabumi

\begin{tabular}{|c|c|c|c|c|c|c|c|c|}
\hline \multirow[b]{3}{*}{ Variabel } & \multicolumn{4}{|c|}{ Seroprevalensi rabies } & \multirow[b]{3}{*}{$p$-value } & \multirow[b]{3}{*}{ OR } & \multicolumn{2}{|c|}{ SK 95\% } \\
\hline & \multicolumn{2}{|c|}{ Positif } & \multicolumn{2}{|c|}{ Negatif } & & & \multirow[b]{2}{*}{ Min } & \multirow[b]{2}{*}{ Maks } \\
\hline & $\begin{array}{c}\text { Juml } \\
\text { ah }\end{array}$ & $\begin{array}{c}\text { Persen } \\
\text { tase } \\
(\%)\end{array}$ & $\begin{array}{c}\text { Juml } \\
\text { ah }\end{array}$ & $\begin{array}{l}\text { Pers } \\
\text { entas } \\
\text { e }(\%)\end{array}$ & & & & \\
\hline \multicolumn{9}{|l|}{ Jenis kelamin } \\
\hline - jantan & 10 & 5,2 & 113 & 59,2 & 0,848 & 1,115 & 0,365 & 4,407 \\
\hline - betina & 5 & 2,6 & 63 & 33,0 & & & & \\
\hline \multicolumn{9}{|l|}{ Umur } \\
\hline - $\quad$ muda (<1 tahun) & 5 & 2,6 & 49 & 25,7 & 0,766 & 1,296 & 0,422 & 3,984 \\
\hline - $\quad$ dewasa ( $\geq 1$ tahun) & 10 & 5,2 & 127 & 66,5 & & & & \\
\hline \multicolumn{9}{|l|}{ Status vaksinasi } \\
\hline - tidak & 11 & 5,8 & 130 & 68,1 & 0,587 & 0,973 & 0,295 & 3,207 \\
\hline - ya & 4 & 2,1 & 46 & 24,1 & & & & \\
\hline Total & 15 & 7,9 & 176 & 92,1 & & & & \\
\hline
\end{tabular}

Keterangan: SK = Selang kepercayaan, OR = Odds ration, Min = Minimal, dan Maks = Maksimal. 
bahwa semakin muda umur anjing, semakin tinggi nilai titer antibodinya; dan semakin tua umur anjing semakin rendah nilai titer antibodi. Hal ini terjadi karena adanya unsur kekebalan maternal dari induk ke anak anjing yang masih tinggi. Secara alamiah hal tersebut dimungkinkan terlebih dengan adanya kekebalan induk anjing akibat program vaksinasi yang menurunkannya kepada anak anjing atau anjing muda. Namun, Arega et al. (2020) menyatakan bahwa anak anjing berumur di atas enam pekan sudah tidak memiliki maternal antibodi rabies. Jika keberadaan titer antibodi akibat dari program vaksinasi, anjing muda cenderung berisiko lebih tinggi untuk tidak membentuk antibodi (Jakel et al. 2008) karena belum matangnya respons imun sehingga booster vaksinasi diperlukan (Kennedy et al. 2007).

Sementara itu, untuk variabel status vaksinasi memiliki odds ratio bernilai satu tidak ada perbedaan status titer antibodi rabies antara populasi anjing yang tidak divaksinasi dan yang divaksinasi. Hal ini mengindikasikan terjadinya kegagalan pembentukan antibodi saat program vaksinasi sebelumnya atau kegiatan vaksinasi telah lama dikerjakan dan belum ada booster vaksinasi. Vaksinasi rabies yang baik dan sesuai pada anjing berumur enam bulan seharusnya dapat meningkatkan kekebalan yang ditunjukkan adanya seropositif dari status titer antibodinya (Sudarmayasa et al. 2020). Mengamati variabel status vaksinasi ini, terdapat hal yang menarik. Dari 141 ekor anjing yang belum divaksinasi, terdapat 11 ekor $(7,8 \%)$ dengan hasil seropositif rabies, yang berarti ada kemungkinan sirkulasi virus rabies yang terjadi secara alamiah di dalam populasi di area hewan tersebut berada (Gold et al. 2020). Dari 50 anjing yang telah divaksinasi rabies sebelumnya, hanya 4 ekor $(8,0 \%)$ yang memiliki titer antibodi protektif rabies, yang mengindikasikan program vaksinasi yang kurang berhasil.

Selanjutnya, faktor risiko ekstinsik dianalisis pada variabel tipe pemeliharaan dan wilayah pemeliharaan. Tipe dan wilayah pemeliharaan ini diidentifikasi berkait erat dengan mobilitas dan interaksi sesama anjing dan interaksi dengan manusia, yang berisiko transmisi virus rabies. Hasil analisis dari faktor risiko ekstrinsik terhadap seroprevalensi rabies disajikan pada Tabel 3. Terdapat hubungan nyata antara wilayah pemeliharaan anjing dan hasil positif titer antibodi rabies $(p=0,003)$, sementara itu variabel tipe pemeliharaan tidak memiliki hubungan yang nyata. Namun, anjing yang tidak dipelihara dengan baik atau dilepasliarkan dapat memberikan kondisi yang sangat kondusif untuk mengubah suatu daerah menjadi

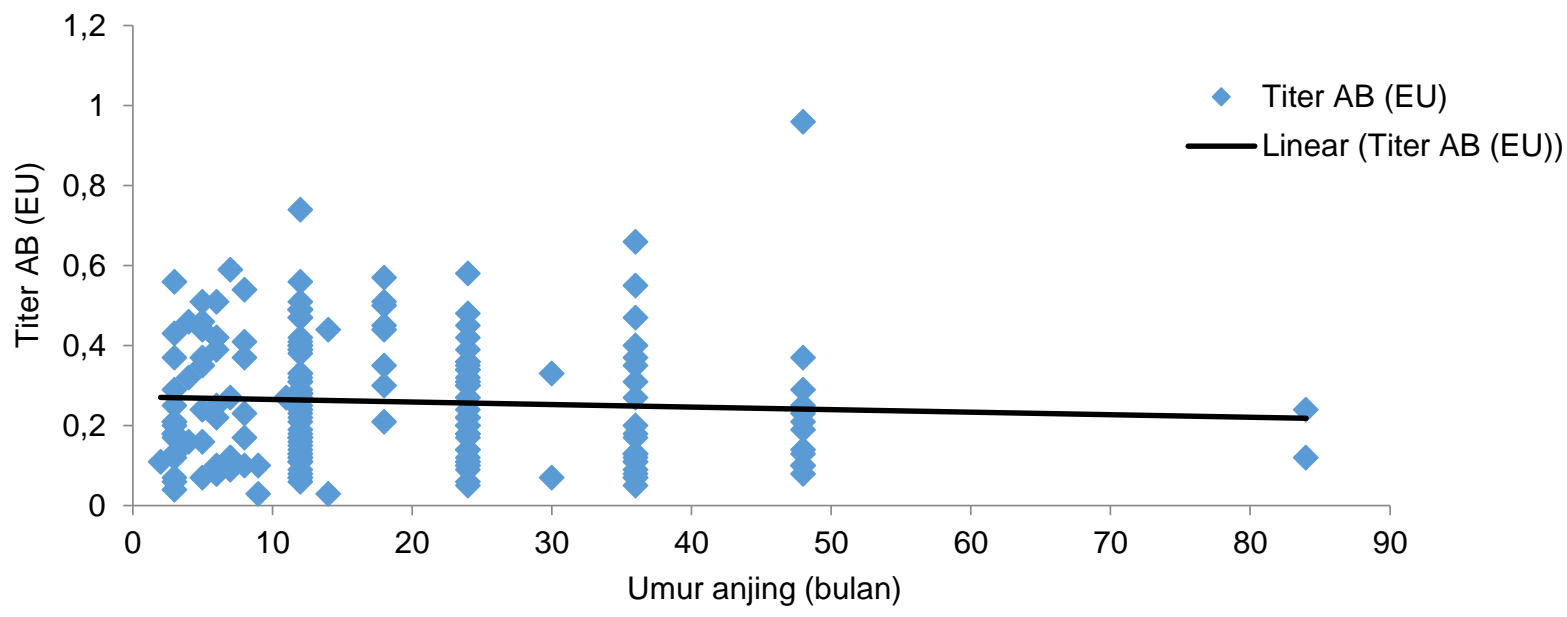

Gambar 2 Hubungan antara umur anjing dengan hasil pengukuran titer antibodi rabies.

Tabel 3 Faktor risiko ekstrinsik terhadap seroprevalensi rabies pada anjing di Kabupaten Sukabumi

\begin{tabular}{|c|c|c|c|c|c|c|c|c|}
\hline \multirow[b]{3}{*}{ Variabel } & \multicolumn{4}{|c|}{ Seroprevalensi rabies } & \multirow[b]{3}{*}{$p$-value } & \multirow[b]{3}{*}{ OR } & \multicolumn{2}{|c|}{ SK 95\% } \\
\hline & \multicolumn{2}{|c|}{ Positif } & \multicolumn{2}{|c|}{ Negatif } & & & \multirow[b]{2}{*}{ Min } & \multirow[b]{2}{*}{ Maks } \\
\hline & $\begin{array}{c}\text { Juml } \\
\text { ah }\end{array}$ & $\begin{array}{c}\text { Perse } \\
\text { ntase } \\
(\%)\end{array}$ & $\begin{array}{c}\text { Juml } \\
\text { ah }\end{array}$ & $\begin{array}{c}\text { Perse } \\
\text { ntase } \\
(\%)\end{array}$ & & & & \\
\hline \multicolumn{9}{|l|}{ Tipe pemeliharaan } \\
\hline - dilepasliarkan & 15 & 7,9 & 170 & 89,0 & 0,608 & 0,919 & 0,880 & 0,959 \\
\hline - dikandangkan & 0 & 0,0 & 6 & 3,1 & & & & \\
\hline \multicolumn{9}{|l|}{ Wilayah pemeliharaan } \\
\hline - pesisir pantai & 12 & 6,3 & 72 & 37,7 & $0,003^{*}$ & 5,778 & 1,574 & 21,208 \\
\hline - $\quad$ perbukitan & 3 & 1,6 & 104 & 54,5 & & & & \\
\hline Total & 15 & 7,9 & 176 & 92,1 & & & & \\
\hline
\end{tabular}

Keterangan: *berhubungan nyata pada $p<0,05 . \mathrm{SK}=$ Selang kepercayaan, OR $=$ Odds ration, Min $=$ Minimal, dan Maks $=$ Maksimal. 
endemis rabies (Kardiwinata et al. 2012). Anjing terinfeksi rabies yang bebas berkeliaran berpotensi menjadi sumber infeksi bagi anjing lain dan juga membahayakan masyarakat sekitar akibat zoonosis. Dibia et al. (2015) juga menyampaikan bahwa adanya kontak antaranjing dapat meningkatkan risiko kejadian rabies sebanyak 12,5 kali lebih tinggi.

Berikutnya, hasil penelitian ini membuktikan bahwa anjing yang dipelihara di wilayah pesisir pantai kemungkinan 5,8 $(1,6-21,2)$ kali lebih besar memiliki seropositif terhadap rabies dibandingkan dengan anjing yang dipelihara di wilayah perbukitan. Wilayah pesisir pantai lebih memiliki jangkauan jelajah yang lebih luas bagi anjing untuk bergerak dan berpindah. Hal ini memudahkan anjing yang terinfeksi rabies untuk berinteraksi dengan anjing lainnya dalam jangkauan yang luas. Sementara itu, wilayah perbukitan memiliki daya jelajah yang terbatas karena unsur topografi dan vegetasi yang dapat menghambat mobilitas anjing untuk berinteraksi dengan anjing lainnya. Hal ini tentu dapat meminimumkan risiko penularan rabies di wilayah pegunungan.

Penjelasan lain dari hasil ini adalah kemudahan petugas kesehatan hewan untuk melakukan vaksinasi di wilayah pesisir pantai yang memiliki topografi landai sehingga dapat memperluas cakupan vaksinasi pada anjing yang berada di wilayah tersebut. Hal ini mengakibatkan titer antibodi rabies lebih banyak didapatkan oleh anjing di wilayah pesisir pantai akibat dari program vaksinasi. Lain halnya dengan program vaksinasi rabies di wilayah pegunungan yang memiliki tantangan topografi tersendiri guna mendapatkan cakupan yang baik. Dengan demikian, ada kemungkinan banyak anjing yang tidak tevaksinasi yang mengakibatkan titer antibodi pada anjing akibat vaksinasi di wilayah tersebut menjadi lebih rendah. Keterjangkauan tempat dilaksanakannya vaksinasi rabies sangat memengaruhi partisipasi pemilik anjing untuk ikut serta dalam program pengendalian rabies (Bayene et al. 2018) sehingga faktor topografi menjadi penting (Castillo-Neyra et al. 2017).

Penelitian ini membuktikan pentingnya program vaksinasi rabies yang sesuai prosedur untuk dapat meningkatkan titer antibodi protektif dan kegiatan tersebut dapat dijalankan rutin setahun sekali untuk tetap menjaga kekebalan kelompok dari populasi anjing. Wilayah dengan status endemis rabies diharapkan memiliki cakupan minimum $70 \%$ dari seluruh populasi anjing tiap tahunnya (Wallace et al. 2017). Vaksinasi massal dapat berhasil dilaksanakan dengan mempertimbangkan faktor yang mendukung partisipasi pemilik anjing dalam program pengendalian tersebut, yakni dengan meningkatkan pengetahuan mereka terkait bahaya rabies (Wicaksono et al. 2019). Peningkatan pengetahuan pemilik anjing melalui penyuluhan dan pendampingan berkala (Wicaksono dan Sudarwanto 2016; Laager et al. 2019). Pelaksanaan vaksinasi dapat sukses dengan membentuk dan melibatkan kader kesehatan terintegrasi (Sudarnika et al. 2019) dalam rangka mendukung tugas tenaga kesehatan hewan di lapangan.

\section{KESIMPULAN}

Seroprevalensi rabies pada anjing di kedua daerah endemis Kabupaten Sukabumi adalah 7,9\% $(4,9-10,9 \%)$. Mayoritas anjing memiliki titer antibodi yang rendah di bawah 0,5 EU, dengan rataan 0,23 EU dengan nilai minimum $0,03 \mathrm{EU}$ dan nilai maksimum 0,96 EU. Pada anjing yang belum divaksinasi, terdapat $7,8 \%$ populasi yang menunjukkan seropositif rabies dan sementara anjing yang telah divaksinasi hanya $8,0 \%$ populasi yang memiliki titer antibodi protektif rabies. Faktor risiko yang berpengaruh nyata pada seroprevalensi rabies pada anjing adalah wilayah pemeliharaan yang memperlihatkan bahwa anjing yang dipelihara di wilayah pesisir pantai memiliki kemungkinan $5,8(1,6-21,2)$ kali lebih tinggi memiliki seropositif terhadap rabies dibandingkan dengan anjing yang dipelihara di wilayah perbukitan.

\section{UCAPAN TERIMA KASIH}

Terima kasih diucapkan kepada Direktorat Jenderal Pendidikan Tinggi yang telah mendanai penelitian ini melalui skema Penelitian Unggulan Perguruan Tinggi. Ucapan terima kasih juga disampaikan kepada Lembaga Penelitian dan Pengabdian Masyarakat, Institut Pertanian Bogor (LPPM IPB) dan Dinas Peternakan Kabupaten Sukabumi yang telah mendukung, membantu, dan menyukseskan pengumpulan data.

\section{DAFTAR PUSTAKA}

Arega S, Conan A, Sabeta CT, Crafford JE, Wentzel J, Reininghaus B, Biggs L, Leisewitz AL, Quan M, Toka F, Knobel DL. 2020. Rabies vaccination of 6 week-old puppies born to immunized mothers: A randomized controlled trial in a high-mortality population of owned, free-roaming dogs. Tropical Medicine and Infectious Disease. 5: 45. https://doi.org/10.3390/tropicalmed5010045

Bayene TR, Mindaye B, Leta S, Cernicchiaro N, Revie CW. 2018. Understanding factors influencing dog owners' intention to vaccinate against rabies evaluated using health belief model constructs. Frontiers in Veterinary Science 5: 159. https://doi.org/10.3389/fvets.2018.00159

Blackwood JC, Streicker DG, Altizer S, Rohani P. 2013. Resolving the roles of immunity, pathogenesis, and immigration for rabies persistence in vampire bats. PNAS 110(51): 20837-20842. https://doi.org/ $10.1073 /$ pnas. 1308817110 
Castillo-Neyra R, Brown J, Borrini K, Arevalo C, Levy MZ, Buttenheim A, Hunter GC, Becerra V, Behrman J, Paz-Soldan VA. 2017. Barriers to dog rabies vaccination during an urban rabies outbreak: Qualitative findings from Arequipa, Peru. PLOS Neglected Tropical Diseases 11(3): e0005460. https://doi.org/10.1371/journal.pntd.0005460

Dartini NL, Mahardika IGNK, Putra AAG, Orr HS. 2012. Uji Banding Dua Kit Elisa untuk Deteksi Antibodi terhadap Virus Rabies pada Anjing. Buletin Veteriner BBVet Denpasar. 24(80): 1-7.

Dibia IN, Sumiarto B, Susetya H, Putra AAG, Scott-Orr H. 2015. Analisis faktor risiko kasus rabies pada anjing di Bali. Buletin Veteriner BBVet Denpasar 27(86): 1-16. https://doi.org/10.4142/jvs.2015. 16.4.459

Dinas Peternakan Kabupaten Sukabumi. 2016. Sosialisasi Rabies: Pengendalian Rabies di Kabupaten Sukabumi Tahun 2016. Sukabumi (ID).

Dahlan MS. 2014. Statistik untuk Kedokteran dan Kesehatan: Deskriptif, Bivariat, dan Multivariat. Jakarta (ID): Epidemiologi Indonesia.

Dohoo I, Martin W, Stryhn H. 2009. Veterinary Epidemiologic Research Second Edition. Prince Edward Island (CA): VER Inc.

Gold S, Donnelly CA, Nouvellet P, Woodroffel R. Rabies virus-neutralising antibodies in healthy, unvaccinated individuals: What do they mean for rabies epidemiology?. PLOS Neglected Tropical Diseases 14(2): e0007933. https://doi.org/ 10.1371/journal.pntd.0007933

Hampson K, Coudeville L, Lembo T, Sambo M, Kieffer A, Attlan M. 2005. Estimating the global burden of endemic canine rabies. PLoS Neglected Tropical Diseases 9: 4. https://doi.org/10.1371/journal. pntd.0003709

Jakel V, Konig M, Cussler K, Hanschmann K-M. 2008. Factors influencing the antibody response to vaccination against rabies. Developments in Biologicals. 131: 431-437.

Kardiwinata MP, Sutarga IM, Subrata IM, Suariyani NLP. 2012. SISTEM pemeliharaan anjing sebagai salah satu hewan penular rabies pada penderita rabies di Provinsi Bali Tahun 2011. Indonesian Journal of Public Health. 1(1): 50-54.

Kennedy LJ, Lunt M, Barnes A, McElhinney L, Fooks AR, Baxter DN, Ollier WER. 2007. Factors influencing the antibody response of dogs vaccinated against rabies. Vaccine. 25: 8500-8507. https://doi.org/10.1016/j.vaccine.2007.10.015

Knobel DL, Cleaveland S, Coleman PG, Fevre EM, Meltzer MI, Miranda MEG, Shaw A, Zinsstag J, Meslin FX. 20015. Re-evaluating the burden of rabies in Africa and Asia. Bulletin of the World Health Organization. 83: 360-368.

Laager M, Léchenne M, Naissengar K, Mindekem R, Oussiguere A, Zinsstag J, Chitnis N. 2019. A metapopulation model of dog rabies transmission in N'Djamena, Chad. Journal of Theoretical Biology 462: 408-417. https://doi.org/10.1016/j.jtbi. 2018.11.027

Nugroho DK, Pudjiatmoko, Diarmitha IK, Tum S, Schoonman L. 2013. Analisa Data Surveilans Rabies (2008-2011) di Propinsi Bali, Indonesia. Outbreaks, Surveillance and Investigation Report. 6(2): 8-12.

Prasatya IGMA, Suardana IBK, Suartha IN. 2018. Respons imun anjing lokal jantan umur diatas satu tahun pasca vaksinasi rabies. Indonesia Medicus Veterinus 7(1): 69-75. https://doi.org/10.19087/ imv.2018.7.1.69

Roy SK, Hossain QZ. 2014. Biosecurity of poultry worker related to avian influenza in Bangladesh. International Journal of Public Health Science. 4(3): 267-275. https://doi.org/10.11591/ijphs.v3i4.4702

Salomao C, Nacima A, Cuamba L, Gujral L, Amiel A. Baltazar C, Cliff J. Gudo ES. 2017. Epidemiology, clinical features and risk factors for human rabies and animal bites during an outbreak of rabies in Maputo and Matola cities, Mozambique, 2014: Implications for public health interventions for rabies control. PLoS Neglected Tropical Diseases. 11(7): $1-16$.

Sudarmayasa IN, Suardana IBK, Suartha N. 2020. Titer antibodi anjing lokal enam bulan pasca vaksinasi rabies. Buletin Veteriner Udayana 12(1): 50-54. https://doi.org/10.24843/bulvet.2020. v12.i01.p09

Sudarnika E, Lukman DW, Zahid A, Ridwan Y, Wicaksono A. 2019. The Success of the "Kasira" rabies cadres in improving community knowledge and attitudes towards rabies. Advances in Health Sciences Research 19: 71-74. https://doi.org/ 10.2991/isessah-19.2019.20

Tenzin, Dhand N K, Ward MP .2012. Anthropogenic and environmental risk factors for rabies occurrence in Bhutan. Preventive Veterinary Medicine. 107(1-2): 21-26. https://doi.org/10.1016/ j.prevetmed.2012.05.003

Thrusfield M. 2018. Veterinary Epidemiology Fourth Edition. Oxford (GB): John Willey \& Sons Ltd.

Wallace RM, Pees A, Blanton JB, Moore SM. 2017. Risk factors for inadequate antibody response to primary rabies vaccination in dogs under one year of age. PLOS Neglected Tropical Diseases. 11(7): e0005761. https://doi.org/10.1371/journal.pntd.0005761 
Wicaksono A, Sudarwanto M. 2016. Prevalensi mastitis subklinis dan evaluasi mikrobiologis susu peternakan rakyat di Boyolali. Acta Veterinaria Indonesiana 4(2): 51-56. https://doi.org/10.29244/ avi.4.2.51-56

Wicaksono A, Sudarwanto M. 2016. Peningkatan kualitas susu peternakan rakyat di Boyolali melalui program penyuluhan dan pendampingan peternak sapi perah. Agrokreatif Jurnal IImiah Pengabdian kepada Masyarakat 2(2): 55-60. https://doi.org/ 10.29244/agrokreatif.2.2.55-60

Wicaksono A, Sudarnika E, Basri C. 2017. Kondisi biosekuriti tempat penjualan burung terkait avian influenza di wilayah Jakarta. Jurnal Sain Veteriner 35(2): 269-276. https://doi.org/10.22146/ jsv.34701
Wicaksono A, Ridwan Y, Arif R. 2019. Prevalensi dan faktor risiko infeksi hookworm zoonotik pasca pemberian anthelmentik pada anjing. Acta Veterinaria Indonesiana 7(2): 26-32. https:// doi.org/10.29244/avi.7.2.26-32

Wicaksono A, Zahid A, Sudarnika E, Lukman DW, Ridwan $Y$. Factors that influence rabies dog vaccination among dogs' owner in Sukabumi District, West Java. Advances in Health Sciences Research 19: 21-23.

Wilde $\mathrm{H}$, Hemachudhaa $\mathrm{T}$, Khawplodb $\mathrm{P}$, Tepsumethanona V, Wacharapluesadeeb S, Lumlertdachab B. 2007. Rabies 2007: perspective from Asia. Asian Biomedicine. 1: 345-357. 